\title{
Zoonotic parasites in wild animals such as carnivores and primates that are traded illegally in Brazil
}

\author{
Parasitos zoonóticos em animais silvestres como carnívoros e \\ primatas comercializados ilegalmente no Brasil
}

\author{
Victor Fernando Santana Lima' (1), Rafael Antonio Nascimento Ramos² (1), Alessio Giannelli3 (1), \\ Sofia Cerqueira Schettino ${ }^{4}$ [D, André Beal Galina ${ }^{5}$ (D) , Jéssica Cardoso Pessoa de Oliveira ${ }^{6}$ (D) \\ Patrícia Oliveira Meira-Santos ${ }^{7}$ (1) \& Leucio Câmara Alves ${ }^{8 *}$ (1) \\ 'Veterinarian, DSc., Unidade de Medicina Veterinária, Universidade Federal de Sergipe (UFS), Nossa Senhora da Glória, SE, Brazil \\ ${ }^{2}$ Veterinarian, DSc., Laboratório de Parasitologia, Universidade Federal do Agreste de Pernambuco (UFAPE), Garanhuns, PE, Brazil \\ ${ }^{3}$ Veterinarian, PhD, Poulpharm BVBA, Izegem, Belgium \\ ${ }^{4}$ Biologist, MSc, Departamento de Medicina Veterinária, UFS, São Cristóvão, SE, Brazil \\ ${ }^{5}$ Biologist, MSc, Instituto Brasileiro de Meio Ambiente, Aracaju, SE, Brazil \\ ${ }^{6}$ Biologist, MSc, Laboratório de Parasitologia, UFAPE, Garanhuns, PE, Brazil \\ `Veterinarian, DSc., Departamento de Medicina Veterinária, UFS, São Cristóvão, SE, Brazil \\ 8 Veterinarian, DSc., Departamento de Medicina Veterinária, Universidade Federal Rural de Pernambuco (UFRPE), Recife, PE, Brazil
}

\begin{abstract}
Brazil accounts for around 20\% of all animal species, but these are constantly threatened by illegal anthropic activities. Unfortunately, animal dealers are totally unaware of the sanitary risks among wild animals, or that occurrences of parasites in these animals are bioindicators for their current sanitary status within the ecosystem in which they live. This status is an important parameter with regard to assessing the spreading of pathogens. Therefore, the aim of this study was to perform a survey of zoonotic parasites in carnivores and non-human primates that are illegally traded in Brazil. Between June 2016 and July 2017, 43 wild animals (20 carnivores and 23 non-human primates) were presented at the Wild Animal Screening Center of Sergipe (CETAS/SE). Fecal and blood samples were obtained and analyzed to detect occurrences of pathogens of medical and veterinary importance, such as Cryptosporidium spp., Giardia spp., Dirofilaria immitis, Leishmania infantum, Leishmania braziliensis, Toxoplasma gondii, Trypanosoma cruzi and gastrointestinal helminths. Out of all the animals analyzed, 55.8\% (24/43) were found to be positive for at least one parasite species, i.e. $41.7 \%$ and $58.3 \%$ of the carnivores and non-human primates, respectively. However, all the animals were negative for $D$. immitis, L. braziliensis and T. cruzi. These findings demonstrate that illegally traded wild animals may represent a risk to public health because of absence of sanitary control during their transportation. Therefore, preventive measures might be employed to avoid infection of these animals and people in close contact with them.
\end{abstract}

Keywords: Giardia, Cryptosporidium, zoonotic role, wild animal traffic.

\section{Resumo}

O Brasil abriga cerca de 20\% de todas as espécies animais existentes no mundo que são continuamente ameaçadas pelas ações antrópicas. Infelizmente, os comerciantes de animais não são suficientemente esclarecidos em relação à ameaça sanitária que representam a vida silvestre, assim como sobre a ocorrência de parasitos que nestes animais funcionam como bio-indicadores do status sanitário do ecossistema, visto serem importantes parâmetros para avaliar a dispersão de patógenos. Portanto, objetivaram-se neste estudo a pesquisa de parasitos zoonóticos em carnívoros eprimatas ilegalmente comercializados no Brasil. Entre Junho de 2016 e Julho de 2017, 43 animais silvestres (20 carnívoros e 23 primatas) foram recebidos no Centro de Triagem de Animais Silvestres de Sergipe (CETAS/SE). Amostras fecais esanguíneas foram obtidas eanalisadas para detectar a presença de patógenos deimportância médico-veterinária como espécies de Cryptosporidium e Giardia, Dirofilaria immitis, Leishmania infantum, Leishmania braziliensis, Toxoplasma gondii, Trypanosoma cruzi e helmintos gastrintestinais. De todas as amostras analisadas, 55,8\% (24/43) foram positivas a pelo menos um agente etiológico testado, sendo 41,7\% e 58,3\% carnívoros e primatas, respectivamente. Todas as amostras foram negativas a D. immitis, L. braziliensis e T. cruzi. Estes achados demonstram que o comércio ilegal de animais silvestres pode representar risco a saúde publica e a saúde destes animais devido à ausência demedidas sanitárias durante o deslocamento. Por fim, medidas preventivas devem ser propostas para evitar a infecção destes animais e consequentemente das pessoas que os manipulam.

Palavras-chave: Giardia, Cryptosporidium, importância zoonótica, comércio ilegal de animais.

\section{BJ $\mathrm{M}$}

How to cite: Lima, V.F.S., Ramos, R. A. N., Giannelli, A., Schettino, S. C., Galina, A. B., Oliveira, J. C. P., Meira-Santos, P. O., \&Alves, L. C. (2021). Zoonotic parasites in wild animals such as carnivores and primates that are traded illegally in Brazil. Brazilian Journal of Veterinary Medicine, 43, e113720. http:// dx.doi.org/10.29374/2527-2179.bjvm113720

Received July 13, 2020.

Accepted August 03, 2020.

\section{*Correspondence}

Leucio Câmara Alves

Departamento de Medicina Veterinária, Universidade Federal Rural de Pernambuco - UFRPE

Rua Dom Manuel de Medeiros, s/n - Dois Irmãos

CEP 52171-900 - Recife (PE), Brasil

E-mail: leucioalves@gmail.com 


\section{Introduction}

Brazil is the fifth largest country on the planet with a wide diversity of animal species. It has been estimated that about $20 \%$ of all animal species live in this region, in the different biomes such as the Atlantic forest, Pampas, Cerrado, Pantanal, Amazonia and Caatinga. Amongst these animals, at least 732 species are wild mammals (Instituto Chico Mendes de Conservação da Biodiversidade, 2017).

Despite this great richness, these animals are constantly threatened due to anthropic activities such as deforestation, water pollution and, especially, wild-animal trafficking (Marchini et al., 2011). Recently, the expansion of urban areas has increased the chances of close interaction between animals and humans and, consequently, the spreading of several zoonotic pathogens (Krauss et al., 2003; Taylor et al., 2001; World Health Organization, 2004).

Trafficking of wild animals has been considered to be the third most important illegal activity in the world, after the trade in illegal weapons and drugs, with incalculable damage to the preservation of wildlife. In Brazil, it has been estimated that 38 million wild animals are taken from their natural habitats, which may lead to income of up to 2.5 billion dollars per year (Rede Nacional de Combate ao Tráfico de Animais Silvestres, 2011). The consequences of the illegal trade in wild animals are immeasurable, especially from a One Health perspective, since these animals are acquired without any sanitary control and may play an important role as carriers of pathogens (Hernandez \& Carvalho, 2006; Pavlin et al., 2009).

Amongst these pathogens, parasites (e.g. Dirofilaria spp., Ancylostoma spp., Toxocara spp., Toxoplasma gondii and Leishmania spp.) have acquired great importance in this close relationship between humans and wild animals. For instance, the distribution of leishmaniasis in Brazil has shifted from rural and forested regions to urban areas (Harhay et al., 2011). The close interaction between humans and synanthropic animals (e.g. wild canids and marsupials), which serve as reservoirs for the causative agent of leishmaniasis, has been incriminated as an important factor assisting this event (Allen et al., 2017; Weiss, 2008). In addition to leishmaniasis, other protozoan diseases such as toxoplasmosis and Chagas disease (American trypanosomiasis) are caused by pathogens that have been gradually introduced into urban areas through wild animal reservoirs (Roque \& Jansen, 2014). Occurrences of gastrointestinal parasites of medical and veterinary concern in these animals are noteworthy. For instance, Baylisascaris procyonis affects raccoons (Procyon lotor) (Sorvillo et al., 2002) and Ancylostoma spp., Strongyloides spp. (Lima et al., 2017), Cryptosporidium spp. and Giardia spp. (Debenham et al., 2017) affect other wild canids and nonhuman primates, along with human beings.

Parasitism in wild animals is a bioindicator of the current situation in ecosystems. This is an important parameter for assessing the spreading of pathogens and behavioral alterations (Bongers \& Ferris, 1999; Lymbery, 2005). Although knowledge of parasite fauna had been pivotal to conservation of wild animals, this fauna has been poorly studied worldwide (Polley, 2005). Moreover, the sanitary consequences of the illegal trade has not been discussed anywhere. Therefore, the aim of this study was to perform a survey of zoonotic parasites in carnivores and non-human primates that had been subjected to wild-animal trafficking activities in Brazil.

\section{Material and methods}

\section{Animals and sampling}

Between June 2016 and July 2017, a total of 43 wild animals were attended at the Wild Animal Screening Center of Sergipe (CETAS/SE). These comprised 20 individuals belonging to carnivore species: six of Cerdocyon thous, one of Leopardus pardalis, four of Nasua nasua and nine of Procyon cancrivorus; and 23 individuals belonging to non-human primate species: 17 of Callithrix jacchus and six of Sapajus libidinosus. All of these animals had been rescued from traffickers by a local government environmental department or had been voluntarily handed over by unofficial breeders.

Initially, all the specimens were restrained and a physical examination was performed. When necessary, a combination of ketamine chloride $(8 \mathrm{mg} / \mathrm{kg})$ and xylazine $(0.8 \mathrm{mg} / \mathrm{kg})$ was used for sedation. Feces samples were obtained from each animal after spontaneous defecation and were stored in plastic vials containing 10\% formalin solution until laboratory processing. In addition, 
blood samples were collected through venipuncture and, when skin lesions were observed, these were scraped and the material was put onto glass slides for further analysis. After recovery, most of the animals were released into their natural environment. Species that were unable to survive in nature were maintained at CETAS/SE.

\section{Laboratory procedures}

\section{Fecal examination}

The samples were initially processed using the FLOTAC technique (Cringoli et al., 2010), to search for eggs, cysts, oocysts and/or larvae of gastrointestinal parasites. In addition, the material was analyzed through the method of centrifugal-sedimentation in formalin-ether solution with Kinyoun staining, to search for Cryptosporidium spp. (Brasil, 1996). Lastly, a direct immunofluorescence test (Merifluor ${ }^{\circledR}$ Cryptosporidium/Giardia kit, Meridian Bioscience) was performed to detect cysts and oocysts of Giardia spp. and Cryptosporidium spp., respectively.

All the parasite structures observed here were identified in accordance with previous morphological descriptions (Bowman, 2013; Taylor et al., 2007).

\section{Molecular analysis}

Genomic DNA was extracted using a commercial kit (Tissue \& Blood Qiamp, QIAGEN) in accordance with the manufacturer's recommendations. Afterwards, a PCR was carried out to search for DNA of Dirofilaria immitis, L. infantum, L. braziliensis, T. gondii and T. cruzi (Table 1). Positive and negative controls were used in each reaction, and the amplified products were analyzed through electrophoresis on 1.5\% agar gel and finally viewed under ultraviolet light.

Table 1. Primers used in this study.

\begin{tabular}{|c|c|c|}
\hline Parasites & Primes & Reference \\
\hline Dirofilaria immitis & $\begin{array}{l}\text { Fila12SF: 5' - CGGGAGTAAAGTTTTGTTTAAACCG-3 } \\
\text { 'and Fila12SR: 5'-CATTGACGGATGGTTTGTACCAC-3' }\end{array}$ & Otranto et al. (2011) \\
\hline Leishmania donovani & $\begin{array}{l}\text { MC1: 5' - GTTAGCCGATGGTGGTCTTG - 3') and MC2: } \\
\text { 5' - CACCCATTTTTCCGATTTTG - 3' }\end{array}$ & Cortes et al. (2004) \\
\hline Leishmania braziliensis & $\begin{array}{l}\text { B1: 5' - GGGGTTGGTGTAATATAGTGG - 3' and B2: 5' - } \\
\text { CTAATTGTGCACGGGGAGG - 3') }\end{array}$ & $\begin{array}{l}\text { Reithinger et al. } \\
\text { (2000) }\end{array}$ \\
\hline Toxoplasmagondii & $\begin{array}{l}\text { NN1: 5'- CCTTTGAATCCCAAGCAAAACATGAG-3'and } \\
\text { NN2: 5'- GCGAGCCAAGACATCCATTGCTGA-3'; } \\
\text { Tg-NP1: 5'- GTGATAGTATCGAAAGGTAT-3' and } \\
\text { Tg-NP2: 5'- ACTCTCTCTCAAATGTTCCT-3' }\end{array}$ & $\begin{array}{l}\text { Hurtado et al. } \\
\text { (2001) }\end{array}$ \\
\hline Trypanosoma cruzi & $\begin{array}{l}\text { S35: 5'- AAATAATGTACGGG(T/G)GAGATGCATGA-3' } \\
\text { and S36: 5'- GGGTTCGATGGGGTTGGTGT-3' }\end{array}$ & Avila et al. (1991) \\
\hline
\end{tabular}

\section{Data analysis}

The data were statistically analyzed for absolute and relative frequencies. The chi-square test with Yates correction was used to compare positivity between different genders, ages and provenance. The significance level was set at $5 \%$. All analyses were performed using the BioEstat statistical software, version 5.0 (Ayres et al., 2007).

\section{Results}

Out of all the animals analyzed, 55.8\% (24/43) were found to be positive for at least one parasite through at least one of the techniques used. These positive animals comprised $41.7 \%$ and $58.3 \%$ of the carnivores and non-human primates ( $p<0.00001)$, respectively.

Nine genera and/or species of zoonotic parasites were detected in this study, among which 33.5\% (3/9) and 66.5\% (6/9) were helminths and protozoa, respectively $(p<0.00001)$. 
All the parasites observed here were distributed among the following seven families: Ancylostomatidae, Entamoebidae, Hexamitidae, Sarcocystidae, Strongyloididae, Taeniidae and Trypanosomatidae.

The overall positivity rates according to animal species and method used are shown in Tables 2 and 3. All the animals were found to be negative for D. immitis, L. braziliensis and T. cruzi.

Coinfections were observed in $20.8 \%$ (5/24) of the animals. Three types of parasite interaction were found:1) Ancylostoma spp + Cryptosporidium spp. + Toxocara cati + L. infantum in L. pardalis; 2) L. infantum + T. gondii in C. thous; and 3) Cryptosporidium spp. + Giardia spp. in C. jacchus and S. libidinosus.

Table 2. Zoonotic parasites in wild carnivores from the traffic of wild animals in the Northeastern of Brazil.

\begin{tabular}{|c|c|c|c|c|c|c|}
\hline \multirow[b]{2}{*}{ Parasites } & \multicolumn{4}{|c|}{ Species \% (n/N) } & \multirow{2}{*}{$\begin{array}{l}\text { Overall } \\
\text { Positivity }\end{array}$} & \multirow[b]{2}{*}{ Test Methods } \\
\hline & $\begin{array}{l}\text { Cerdocyon } \\
\text { thous }\end{array}$ & $\begin{array}{l}\text { Leopardus } \\
\text { pardalis }\end{array}$ & $\begin{array}{l}\text { Nasua } \\
\text { nasua }\end{array}$ & $\begin{array}{l}\text { Procyon } \\
\text { cancrivorus }\end{array}$ & & \\
\hline Ancylostoma spp. & $33.3(2 / 6)$ & $100(1 / 1)$ & $\mathrm{O}(\mathrm{O} / 4)$ & $\mathrm{O}(0 / 9)$ & $15.0(3 / 20)$ & FLOTAC $^{\circledR}$ \\
\hline Cryptosporidium spp. & $16.6(1 / 6)$ & $100(1 / 1)$ & $25.0(1 / 4)$ & $22.2(2 / 9)$ & $25.0(5 / 20)$ & $\begin{array}{l}\text { Centrifugal-sedimentation and } \\
\text { Merifluor }^{\circledR}\end{array}$ \\
\hline Entamoeba spp. & $0(0 / 6)$ & $\mathrm{O}(0 / 1)$ & $\mathrm{O}(0 / 4)$ & $11.1(1 / 9)$ & $10.0(2 / 20)$ & FLOTAC $^{\circledR}$ \\
\hline Giardia sp. & $16.6(1 / 6)$ & $\mathrm{O}(\mathrm{O} / 1)$ & $\mathrm{O}(\mathrm{O} / 4)$ & $11.1(1 / 9)$ & $10.0(2 / 20)$ & FLOTAC $^{\circledR}$ and Merifluor ${ }^{\circledR}$ \\
\hline Strongyloides spp. & $50.0(3 / 6)$ & $\mathrm{O}(\mathrm{O} / 1)$ & $\mathrm{O}(0 / 4)$ & $11.1(1 / 9)$ & $20.0(4 / 20)$ & FLOTAC $^{\circledR}$ \\
\hline Toxocara cati & $\mathrm{O}(0 / 6)$ & $100(1 / 1)$ & $\mathrm{O}(0 / 4)$ & $\mathrm{O}(0 / 9)$ & $5.0(1 / 20)$ & FLOTAC $^{\circledast}$ \\
\hline Leishmania infantum & $16.6(1 / 6)$ & $100(1 / 1)$ & $\mathrm{O}(\mathrm{O} / 4)$ & $\mathrm{O}(0 / 9)$ & $10.0(2 / 20)$ & Blood smear, Citologoly and PCR \\
\hline Toxoplasma gondii & $50.0(3 / 6)$ & $\mathrm{O}(\mathrm{O} / \mathrm{1})$ & $\mathrm{O}(\mathrm{O} / 4)$ & $11.1(1 / 9)$ & $\mathrm{O}(0 / 20)$ & Nested PCR \\
\hline
\end{tabular}

Table 3. Zoonotic parasites in nonhuman primates from the traffic of wild animals in the Northeastern of Brazil.

\begin{tabular}{|c|c|c|c|c|}
\hline \multirow[b]{2}{*}{ Parasites } & \multicolumn{3}{|c|}{ Species \% (n/N) } & \multirow[b]{2}{*}{ Test Methods } \\
\hline & Callithrix jacchus & $\begin{array}{c}\text { Sapajus } \\
\text { libidinosus }\end{array}$ & Overall Positivity & \\
\hline Ancylostoma spp. & $5.8(1 / 17)$ & $\mathrm{O}(0 / 6)$ & $4.3(1 / 23)$ & FLOTAC $^{\circledR}$ \\
\hline Cryptosporidium spp. & $5.8(1 / 17)$ & $33.3(2 / 6)$ & $13.0(3 / 23)$ & Centrifugal-sedimentation and Merifluor ${ }^{\circledR}$ \\
\hline Entamoeba spp. & $\mathrm{O}(0 / 17)$ & $16.6(1 / 6)$ & $4.3(1 / 23)$ & FLOTAC ${ }^{\circledast}$ \\
\hline Giardia spp. & $11.7(2 / 17)$ & $66.6(4 / 6)$ & $26.0(6 / 23)$ & FLOTAC $^{\circledR}$ and Merifluor ${ }^{\circledR}$ \\
\hline Strongyloides spp. & $\mathrm{O}(\mathrm{O} / 17)$ & $16.6(1 / 6)$ & $4.3(1 / 23)$ & FLOTAC $^{\circledR}$ \\
\hline Taenia spp. & $5.8(1 / 17)$ & $\mathrm{O}(0 / 6)$ & $4.3(1 / 23)$ & FLOTAC $^{\circledR}$ \\
\hline Toxoplasma gondii & $11.7(2 / 17)$ & $\mathrm{O}(\mathrm{O} / 6)$ & $8.6(2 / 23)$ & Nested PCR \\
\hline
\end{tabular}

\section{Discussion}

This study assessed the parasite fauna of wild animals that had been rescued from traffickers. It was demonstrated that these animals are susceptible to a wide range of pathogens of medical and veterinary concern. The overall positivity rate observed here $(55.8 \% ; 24 / 43)$ was higher than what has been reported in other studies, but it is important to note that, in the present study, a wide range of parasites (ranging from gastrointestinal to hematological parasites) were found using different diagnostic tools (Leite et al., 2008; Santos et al., 2015). Interestingly, both nematodes and protozoa with zoonotic potential were detected in the present study. Among the nematodes, eggs of Strongyloides sp. were the most common finding, both in carnivores and in non-human primates. This demonstrates the diversity of hosts that this parasite may infect. Moreover, eggs 
of Ancylostoma spp., Toxocara spp. and Taenia spp. were present in carnivores and non-human primates, respectively. The zoonotic role of these species is well documented, but it is important to note that other zoonotic species such as Cryptosporidium spp., Giardia spp. and Entamoeba spp. may be present (Hunter \& Thompson, 2005; Mak, 2004).

Gastrointestinal infection by protozoa was also observed in both groups of animals, among which Cryptosporidium and Giardia were the most important agents detected. Despite the zoonotic potential, these protozoa are an important cause of diarrhea in animals. This type of parasitism has been reported worldwide (Holsback et al., 2013). The coinfection between Cryptosporidium and Giardia that was observed in Cerdocyon thous (crab-eating fox), Procyon cancrivorus (crab-eating raccoon), Callithrixjacchus (common marmoset) and Sapajus libidinous (black-striped capuchin) is worrying since there is evidence of clinical manifestations of these pathogens in these animals (Graczyk et al., 2002). In addition, a study on the genotypes of these protozoa demonstrated that humans are most likely the source of infection for these animals (Soares et al., 2011).

Among all parasites observed in this study, Leishmania spp. and T.gondii have been considered to be the ones of greatest public health importance. It is known that T. gondii parasitizes a wide range of animals: the infection reported here may have arisen through these animals' feeding behavior and through environmental contamination by the feces of felids (Cubas et al., 2006). In addition, it has been demonstrated that the presence of small rodents and birds in these animals' shelters may represent a risk factor for occurrences of T. gondii infection (Valentini et al., 2004). Conversely, the detection of Leishmania spp. DNA in C. thous and L. pardalis highlights the role of these animals as potential reservoirs for this parasite, since this type of parasitism has already been reported elsewhere (Roque \& Jansen, 2014). Absence of clinical signs has been a common finding among wild animals infected by Leishmania spp., but in the present study both of the animals that were positive for this parasite exhibited signs such as dermatopathy and ocular lesions, similar to those observed in cases of visceral leishmaniasis among canids (Figure 1).

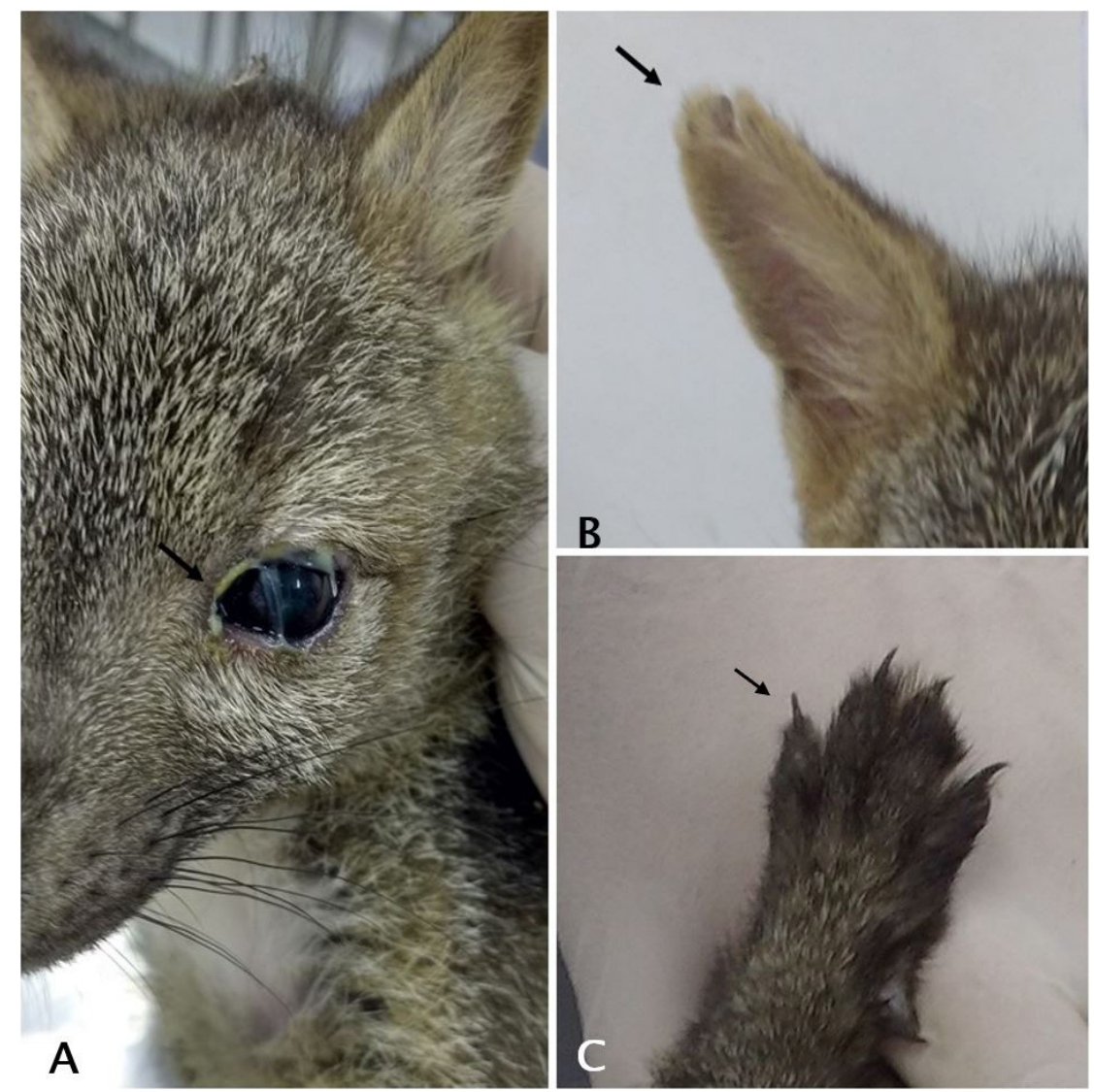

Figure 1. Lesions (arrows) of visceral leishmaniasis in Cerdocyon thous. (A) Ocular lesion; (B) Dermatopathy; and (C) Onychogryphosis. 
Every year, around 38 million animals are lost from Brazil's stock of fauna to the international illegal trade (Rosen \& Smith, 2010). Although the harms caused by this activity has been considered immeasurable, three main troubles deserve to be highlighted:1) the economic impact caused by the high untaxed revenues accrued through this activity, which constitute losses for local governments; 2 ) the ecological issues that this activity causes, given that it accelerates the process of wild animal extinction and may lead to imbalance of ecological interactions due to the introduction of exotic species; and 3) the risk to public health due to absence of sanitary control over these animals, which are illegally traded worldwide (Hernandez \& Carvalho, 2006; Pavlin et al., 2009).

From an epidemiological point of view, these findings are important since most of these animals present synanthropic behavior and form a link between rural/forested areas and urban areas. In addition, many of the pathogens detected here (e.g. Giardia and Cryptosporidium) are considered to be opportunistic and easily transmitted through ingestion or inhalation (Heller et al., 2014). Therefore, preventive measures might be used to avoid infection of these animals and people who come into close contact with these animals.

\section{Conclusion}

Carnivores and non-human primates that have been subjected to wild-animal trafficking activities may act as reservoirs for several pathogens of medical and veterinary importance. They are important bioindicators of the health status of the ecosystem.

\section{Ethics statement}

This study was approved by the Instituto Chico Mendes de Conservação da Biodiversidade (ICMBio) (license number:59962-1) and was conducted in accordance with the recommendations of the Brazilian College of Animal Experimentation.

\section{Financial support}

None

\section{Conflict of interests}

No conflict of interests declared concerning the publication of this article.

\section{Authors' contributions}

VFS L, RANR, AG, LCA -Development of methodology; preparation and writing the inicial draft, Review and Editing manuscript and application of statistical study data . SCS, ABG, JCPO, POMS- Review and Editing manuscript

\section{Availability of complementary results}

All the procedures carried out in this study were approved by the Ethics Committee on Animal Use (CEUA) of the Federal Rural University of Pernambuco (Protocol no. 127/2015) and by Brazil's Biodiversity Authorization and Information System (SISBIO), under Protocol no. 50588-1.

The study was carried out at Departamento de Medicina Veterinária, Universidade Federal Rural de Pernambuco - UFRPE, Recife, PE, Brasil.

\section{References}

Allen, T., Murray, K. A., Zambrana-Torrelio, C., Morse, S. S., Rondinini, C., Marco, M. D., Breit, N., Olival, K. J., \& Daszak, P. (2017). Global hotspots and correlates of emerging zoonotic diseases. Nature Communications, 8 , 1124. http://dx.doi.org/10.1038/s41467-017-00923-8. PMID:29066781.

Avila, H. A., Sigman, D. S., Cohen, L. M., Millikan, R. C., \& Simpson, L. (1991). Polymerase chain reaction amplification of Trypanosoma cruzi kinetoplast minicircle DNA isolated from whole blood lysates: diagnosis of chronic Chagas' disease. Molecular and Biochemical Parasitology, 48(2), 211-221. http://dx.doi.org/10.1016/01666851(91)90116-N. PMid:1662334. 
Ayres, M., Ayres Junior, M., Ayres, D. L., \& dos Santos, A. A. S. (2007). BioStat aplicações estatísticas nas áreas de ciências bio-médicas (5. ed., 364 p.). Belém: Mamirauá.

Bongers, T., \& Ferris, H. (1999). Nematode community structure as a bioindicator in environmental monitoring. Trends in Ecology \& Evolution, 14(6), 224-228. http://dx.doi.org/10.1016/S0169-5347(98)01583-3. PMid:10354624.

Bowman, D. D. (2013). Georgis' parasitology for veterinarians (10th ed., 496 p.). Saunders.

Brasil. Ministério da Saúde. (1996). Infecções oportunistas por parasitas em AIDS: Técnicas de diagnóstico. Ministério da Saúde.

Cortes, S., Rolão, N., Ramada, J., \& Campino, L. (2004). PCR as a rapid and sensitive tool in the diagnosis of human and canine leishmaniasis using Leishmania donovani s.l.-specific kinetoplastid primers. Transactions of the Royal Society of Tropical Medicine and Hygiene, 98(1), 12-17. http://dx.doi.org/10.1016/S0035-9203(03)000026. PMid:14702834.

Cringoli, G., Rinaldi, L., Maurelli, M. P., \& Utzinger, J. (2010). FLOTAC: new multivalente techniques for qualitative and quantitative copromicroscopic diagnosis of parasites in animals and humans. Nature Protocols, 5(3), 503-515. http://dx.doi.org/10.1038/nprot.2009.235. PMid:20203667.

Cubas, Z. S., Silva, J. C. R., \& Catão-Dias, J. L. (2006). Tratado de animais selvagens. Roca.

Debenham, J. J., Landuyt, H., Troell, K., Tysnes, K., \& Robertson, L. J. (2017). Occurrence of Giardia in Swedish red foxes (Vulpes vulpes). Journal of Wildlife Diseases, 53(3), 649-652. http://dx.doi.org/10.7589/2017-01-002. PMid:28362140.

Graczyk, T. K., Bosco-Nizeyi, J., Ssebide, B., Thompson, R. C., Read, C., \& Cranfield, M. R. (2002). Anthropozoonotic Giardia duodenalis genotype (assemblage) a infections in habitats of free-ranging human-habituated gorillas, Uganda. The Journal of Parasitology, 88(5), 905-909. http://dx.doi.org/10.1645/0022-3395(2002)088[0905:AGD GAA]2.0.CO;2. PMid:12435128.

Harhay, M. O., Olliaro, P. L., Costa, D. L., \& Costa, C. H. (2011). Urban parasitology: visceral leishmaniasis in Brazil. Trends in Parasitology, 27(9), 403-409. http://dx.doi.org/10.1016/j.pt.2011.04.001. PMid:21596622.

Heller, L., Bastos, R. K. X., Vieira, M. B. C., Brito, L. L. A., Mota, S. M. M., Oliveira, A. A., Machado, P. M., Salvador, D. P., \& Cardoso, A. B. (2014). Cryptosporidium oocysts and Giardia cysts: environmental circulation and health risks. Epidemiologia e Serviços de Saúde : Revista do Sistema Unico de Saúde do Brasil, 13, 79-92. http://dx.doi. org/10.5123/S1679-49742004000200002.

Hernandez, E. F. T., \& Carvalho, M. S. (2006). O tráfico de animais silvestres no Estado do Paraná. Acta Scientarium: Human and Social Sciences, 28(2), 257-266. http://dx.doi.org/10.4025/actascihumansoc.v28i2.168.

Holsback, L., Cardoso, M. J., Fagnani, R., \& Patelli, T. H. (2013). Natural infection by endoparasites among freeliving wild animals. Revista Brasileira de Parasitologia Veterinária, 22(2), 302-306. http://dx.doi.org/10.1590/ S1984-29612013005000018. PMid:23778826.

Hunter, P. R., \& Thompson, R. C. (2005). The zoonotic transmission of Giardia and Cryptosporidium. International Journal for Parasitology, 35(11-12), 1181-1190. http://dx.doi.org/10.1016/j.ijpara.2005.07.009. PMid:16159658.

Hurtado, A., Aduriz, G., Moreno, B., Barandika, J., \& García-Pérez, A. L. (2001). Single tube nested PCR for the detection of Toxoplasma gondii in fetal tissues from naturally aborted ewes. Veterinary Parasitology, 102(1-2), 17-27. http://dx.doi.org/10.1016/S0304-4017(01)00526-X. PMid:11705648.

Instituto Chico Mendes de Conservação da Biodiversidade - ICMBio. (2017). Unidades de conservação. IOP Publishing ICMBio. http://www.icmbio. gov.br/portal/unidadesdeconservacao/biomas-brasileiros

Krauss, H., Weber, A., Appel, M., Enders, B., Isenberg, H. D., Schiefer, H. G., Slenczka, W., von Graevenitz, A., \& Zahner, H. (2003). Zoonoses: infectious diseases transmissible from animals to humans. American Society of Microbiology Press. http://dx.doi.org/10.1128/9781555817787.

Leite, T. N., Maja, TDE. A., Ovando, T. M., Cantadori, D. T., Schimidt, L. R., Guércio, A. C., Cavalcanti, A., Lopes, F. M., Da Cunha, I. A., \& Navarro, I. T. (2008). Occurrence of infection Leishmania spp. and Toxoplasma gondii in monkeys (Cebus apella) from Campo Grande, MS. Revista Brasileira de Parasitologia Veterinária, 17(Suppl 1), 307-310. PMid:20059866.

Lima, V. F. S., Ramos, R. A. N., Lepold, R., Borges, J. C. G., Ferreira, C. D., Rinaldi, L., Cringoli, G., \& Alves, L. C. (2017). Gastrointestinal parasites in feral cats and rodents from the Fernando de Noronha Archipelago, Brazil. Revista Brasileira de Parasitologia Veterinária, 26(4), 521-524. http://dx.doi.org/10.1590/s1984-29612017066. PMid:29160359.

Lymbery, A. J. (2005). Parasites and ecosystem health. International Journal for Parasitology, 35(7), 703. http:// dx.doi.org/10.1016/j.ijpara.2005.02.012.

Mak, J. W. (2004). Important zoonotic intestinal protozoan parasites in Asia. Tropical Biomedicine, 21(2), 39-50. PMid:16493397.

Marchini, S., Cavalcanti, S. M. C., \& Paula, R. C. (2011). Predadores silvestres e animais domésticos - Guia prático de convivência. ICMBio.

Otranto, D., Brianti, E., Dantas-Torres, F., Weigl, S., Latrofa, M. S., Gaglio, G., Cauquil, L., Giannetto, S., \& Bain, O. (2011). Morphological and molecular data on the dermal microfilariae of a species of Cercopithifilaria from a dog in Sicily. Veterinary Parasitology, 182(2-4), 221-229. http://dx.doi.org/10.1016/j.vetpar.2011.05.043. PMid:21705146.

Pavlin, B. I., Schloegel, L. M., \& Daszak, P. (2009). Risk of importing zoonotic diseases through wildlife trade, United States. Emerging Infectious Diseases, 15(11), 1721-1726. http://dx.doi.org/10.3201/eid1511.090467. PMid:19891857. 
Polley, L. (2005). Navigating parasites web and parasite flow: emerging and re-emerging parasitic zoonoses of wildlife origin. International Journal for Parasitology, 35(11-12), 1279-1294. http://dx.doi.org/10.1016/j. iipara.2005.07.003. PMid:16168994.

Rede Nacional de Combate ao Tráfico de Animais Silvestres - RENCTAS. (2011). 1st National Report on Wildlife Trafficking. RENCTAS.

Reithinger, R., Lambson, B. E., Barker, D. C., \& Davies, C. R. (2000). Use of PCR to detect Leishmania (Viannia) sp. in dog blood and bone marrow. Journal of Clinical Microbiology, 38(2), 748-751. http://dx.doi.org/10.1128/ JCM.38.2.748-751.2000. PMid:10655379.

Roque, A. L. R., \& Jansen, A. M. (2014). Wild and synanthropic reservoirs of Leishmania species in the Americas. International Journal for Parasitology. Parasites and Wildlife, 3(3), 251-262. http://dx.doi.org/10.1016/j. ijppaw.2014.08.004. PMid:25426421.

Rosen, G. E., \& Smith, K. F. (2010). Summarizing the evidence on the international trade in illegal wildlife. EcoHealth, 7(1), 24-32. http://dx.doi.org/10.1007/s10393-010-0317-y. PMid:20524140.

Santos, P. M. S., Silva, S. G. N., Fonseca, C. F., \& Oliveira, J. B. (2015). Parasitos de aves e mamíferos silvestres em cativeiro no estado de Pernambuco. Pesquisa Veterinária Brasileira, 35(9), 788-794. http://dx.doi.org/10.1590/ S0100-736X2015000900004.

Soares, R. M., de Souza, S. L., Silveira, L. H., Funada, M. R., Richtzenhain, L. J., \& Gennari, S. M. (2011). Genotyping of potentially zoonotic Giardia duodenalis from exotic and wild animals kept in captivity in Brazil. Veterinary Parasitology, 180(3-4), 344-348. http://dx.doi.org/10.1016/j.vetpar.2011.03.049. PMid:21530084.

Sorvillo, F., Ash, L. R., Berlin, O. G., \& Morse, S. A. (2002). Baylisascaris procyonis: an emerging helminthic zoonosis. Emerging Infectious Diseases, 8(4), 355-359. http://dx.doi.org/10.3201/eid0804.010273. PMid:11971766.

Taylor, L. H., Latham, S. M., \& Woolhouse, M. E. (2001). Risk factors for human disease emergence. Philosophical Transactions of the Royal Society of London, 356(1411), 983-989. http://dx.doi.org/10.1098/rstb.2001.0888. PMid:11516376.

Taylor, M. A., Coop, R. L., \& Wall, R. L. (2007). Veterinary parasitology (3rd ed., 874 p.). Wiley.

Valentini, E. J. G., Caprara, A., Souza, S. L. P., Mattaraia, V. G. M., Gennari, S. M., Rodrigues, U. P., Francisco, F. M., \& Soares, R. M. (2004). Investigação sorológica de infecção por Toxoplasma gondii em colônia de macacos da espécie Macaca mulatta. Arquivos do Instituto Biológico, 71, 507-510.

Weiss, L. M. (2008). Zoonotic parasitic diseases: emerging issues and problems. International Journal for Parasitology, 38(11), 1209-1210. http://dx.doi.org/10.1016/j.ijpara.2008.05.005. PMid:18603251.

World Health Organization - WHO. (2004). Globalization and infectious diseases: A review of the linkages. World Health Organization on behalf of the Special Programme for Research and Training in Tropical Diseases. 